\title{
Managing economic feasibility and social relationships: interventions to prevent dysfunctional conflict in public-private partnerships
}

\author{
Louis H. M. J. Lousberg ${ }^{a}$, Hans W. F. Wamelink ${ }^{a}$ and Leon I. A. De Caluwéb \\ ${ }^{\mathrm{a} D e p a r t m e n t ~ o f ~ R e a l ~ E s t a t e ~ \& ~ H o u s i n g, ~ D e l f t ~ U n i v e r s i t y ~ o f ~ T e c h n o l o g y, ~ D e l f t, ~ T h e ~ N e t h e r l a n d s ; ~}{ }^{\mathrm{b}}$ Department of Management \& Organisation, VU \\ University Amsterdam, Amsterdam, The Netherlands
}

\begin{abstract}
Large engineering projects such as urban development projects that are organised as publicprivate partnerships (PPPs) often encounter critical problems that directly affect the partnerships. Literature indicates that characteristics specific to PPPs contribute to these critical problems becoming dysfunctional conflicts. Consequently, objectives are no longer met and projects suffer. This study identified interventions that prevent these dysfunctional conflicts. In the literature, no interventions at an operational level that are suitable for use 'at the negotiating table' and are also applicable for urban development PPP projects were found. Hence, based on a review of literature on interventions, a perspective for action was developed on interventions that are likely to succeed. Subsequently, in a study of 10 cases of urban development PPP projects, these (and other) interventions were found. All interventions can be categorised under economic feasibility or social relationship. We conclude that dysfunctional conflicts in urban development PPP projects can be prevented by managing economic feasibility and social relationships. Under certain conditions, this also seems applicable to other PPPs.
\end{abstract}

\section{KEYWORDS}

Dysfunctional conflict; interventions; public-private partnership; urban

development project

\section{Introduction}

Public-private partnerships (PPPs) are a form of cooperation between the government and private parties for the realisation of certain public and private goals (cf. De Bruijn and Leijten, 2005: 232). Around the world, PPPs are frequently used in large engineering projects such as urban development projects. However, there are substantial differences per country. A distinction can be made between PPPs where financial risks are mutually shared and those in which they are not (cf. Bult-Spiering and Dewulf, 2008, p. 137). The latter are relatively popular in such countries as France, Germany and Portugal (cf. Enterprise Risk Services, 2009). These kinds of PPPs are not covered by this research precisely because they do not involve shared risk capital investment.

PPPs in urban development based on shared risk capital investment (e.g. as in alliances) can involve non-hierarchical relationships. Cooperation between both parties is therefore essential in order to achieve the agreed objectives. Although both parties are aware of this, major conflicts can occur between parties (e.g. local councils and project developers) that damage the project. In other words, the conflict can become dysfunctional. Dysfunctional conflicts are those in which mutual goals are no longer attained, unwanted delays occur, working relations deteriorate, and winning or losing becomes the key issue, despite neither party wanting any of these outcomes (cf. Duke and Geurts, 2004, p. 169; De Dreu, 2005, pp. 77, 48).

The goal of this study was to identify interventions to prevent these dysfunctional conflicts. An intervention is defined here as one of a series of scheduled activities that are intended to improve an organisation's effectiveness (De Caluwé and Vermaak, 2006).

Numerous studies of problems in urban development projects have been conducted since Kouwenhoven (1991) defined several preconditions and procedural conditions for successful PPP in urban development and infrastructure projects. These problems have numerous causes, including conflicts between government and private-sector interests (which seek maximum quality and maximum profitability, respectively), a lack of understanding of interests and positions held by the involved public bodies and private sector, uncertainties about public decision-making processes and poor coordination between various public bodies, a lack of trust and transparency, a lack of joint problem definition and inflated expectations at the project outset (Lousberg, 2012, p. 10; cf. Mahalingam and Delhi, 2012, p. 171).

CONTACT Louis H. M. J. Lousberg I.h.m.j.lousberg@tudelft.nl E Department of Real Estate \& Housing, Delft University of Technology, PO Box 5043, 2600 GA Delft, The Netherlands

C 2016 Informa UK Limited, trading as Taylor \& Francis Group 
These problems can become critical if they threaten the project by, for example, delaying or even halting it.

In the literature, three indications were found of a link between critical problems and dysfunctional conflicts in conjunction with a PPP in urban development projects:

- PPP projects in urban development are complex (Bult-Spiering, 2003, p.332). A key dimension of complexity is uncertainty (De Leeuw, 2002, p. 189; Weening, 2006, p. 22). In uncertain situations, assumptions play a key role and are close to emotionally charged belief (Weick, 1995, p. 114). In an uncertain situation, there is a greater chance of social and emotional conflicts than there is in stable contexts (De Dreu, 2005, pp. 71, 72; Schruijer and Vansina, 2007, p. 208).

- PPP projects in urban development are characterised by the social diversity of public and private parties (Van der Meij et al., 2000, p.39; Bult-Spiering, 2003, p. 260). Social diversity, which includes demographic characteristics, culturally determined value systems and religious convictions, increases the chance of social and emotional conflicts (Jehn, 1997; Pinto, 2004, p. 208).

- The discussion on spatial quality in urban development PPP projects is ambiguous (Teisman, 2004, p. 14). In an ambiguous situation, it appears that, in the absence of objective criteria, players with a different value orientation depend more on personal or professional values when giving meaning to that situation. The clash between different values often adds a political and emotional dimension to the situation (Weick, 1995, p. 93).

All three indications lead to the conclusion that the specific characteristics of a PPS in urban development generate a greater probability of socio-emotional, dysfunctional conflicts. This also means that, in such an environment, critical problems can escalate to become dysfunctional conflicts. The key research question was therefore: Which interventions at an operational level can prevent dysfunctional conflicts in the practice of PPP in urban development projects?

\section{Literature research}

To answer the research question, a literature search was conducted on the basis of two criteria (Lousberg, 2012, p. 39): is the intervention at an operational level suitable for use at the negotiating table and, if so, is this intervention applicable to PPP in urban development?

The literature on negotiation and conflict presents various theories, for example that of constructive controversy (Tjosvold, 1998; Vollmer and Seyr, 2013) and the dual care model (Thomas and Kilmann, 1974), that can be used to create a perspective for action by means of negotiating styles, general rules of thumb and strategies (cf. Saner, 2005). However, this literature does not provide interventions at an operational level and/or confirmation of their applicability in PPP in urban development projects.

The project management, process management and urban development literatures provide solution strategies for existing conflicts and ways to prevent conflicts by using, for example, the mutual gains approach (Evers and Susskind, 2009), but they do not offer interventions at an operational level that are suitable for use at the negotiating table. Recent literature on, for instance, strategies to enhance collaboration in construction projects (e.g. Dewulf and Kadefors, 2012; Brady and Davies, 2014; Castaño et al., 2015) also does not meet one or both of the abovementioned criteria.

Thus, literature does not provide interventions at an operational level suitable for use at the negotiating table or interventions that are applicable to PPP in urban development. We therefore independently developed a perspective of action while also taking into account relevant findings from the literature. First two dimensions are developed, next, interventions which are likely to succeed.

\subsection{Two dimensions: economic feasibility and social relationship}

A previous case study of PPP in urban development projects revealed that the term economic feasibility and various terms relating to social relationships seemed to play a role in identifying the causes of and solutions to dysfunctional conflicts (Lousberg, 2012, p. 37). Other research confirms that economic and social perspectives to describe and clarify the creation and functioning of interaction in PPP in urban development projects need to be distinguished (Bult-Spiering, 2003, pp. 272, 273). Further, the negotiation and conflict management literature distinguishes between two pathways, namely content/result on the one hand and people/relationship on the other (cf. Thomas and Kilmann, 1974; Fisher et al., 2004).

There are thus two dimensions in which interventions that can prevent dysfunctional conflicts can be positioned: economic feasibility and social relationship. Economic feasibility is defined as the relation between price $(=$ costs + revenues $)$ and quality: something is feasible if it has an acceptable price/quality relationship. Social relationship is defined as the interaction between the collaborating actors, where a good relationship is characterised by commitment, trust, 
acceptance and respect (Bult-Spiering, 2003, pp. 269, 271).

\subsection{Interventions from literature that are likely to succeed}

The negotiation and conflict literature provides conflict interventions and conflict context factors (cf. Giebels and Euwema, 2006, p. 150). We start with the former.

\subsubsection{Conflict interventions}

2.2.1.1. Identifying assumptions. The cause of a dysfunctional conflict can be localised in assumptions about oneself and the world, in the belief system that works like a cognitive filter (cf. De Moor, 1991, pp. 19, 115). It was therefore essential to identify those assumptions.

Checking or identifying assumptions appear to be a process primarily of clarification and deconstruction. Clarification implies making the implicit explicit, and here assumptions are presumed to be implicit. Many people simply accept these assumptions. Others, however, believe that they should not be taken at face value. One thing that people are then not aware of is that the other party needs those assumptions in order to form a view of the thought process that it wants to clarify (cf. Smulders, 2006, p. 356). Conversely, the other party is unaware that it needs those assumptions in order to be able to understand that thought process. Deconstruction refers to the capacity to understand or decode what others have constructed (Van Dongen et al., 1996, p. 33). Within the framework of the present study, deconstruction is interpreted as the capacity to decode the problem and solution presentation by identifying the underlying assumptions. When there is a danger that a conflict might escalate, formulating or reformulating each other's assumptions or identifying assumptions based on differences in perception appears to be an essential step towards preventing a dysfunctional conflict.

The literature also shows that the effective application of conflict styles generally does not mean that there is a preferred strategy, but rather a mixed strategy, with the simultaneous or sequential use of two styles: competition and cooperation. The greatest effect is achieved if one first competes and then collaborates to find solutions (cf. Giebels and Euwema, 2006, p. 71). However, in Giebels' study, this was not specified in terms of action at the operational level. These strategies of competing and collaborating are specified below in confronting and exploring, respectively. Confronting can, in fact, be regarded as a form of competing or forcing - namely, ensuring that your problem also becomes the problem of the other (Giebels and Euwema, 2006, p. 67) - whereas exploring can be regarded as a form of cooperation or problem-solving. One opts for an open approach and seeks a joint solution (Giebels and Euwema, 2006, p. 66).

2.2.1.2. Confronting. The literature studied suggests a connection between seeking confrontation and preventing conflicts: that is, robust and constructively contested differences of opinion improve mutual relationships and boost confidence in future cooperation (De Dreu, 2005, p. 70). De Dreu based these findings on experimental research by Tjosvold and the field study that he performed with Tjosvold involving 60 managers in two Dutch organisations (2005, p. 70). The question is whether the suggested link exists and, if so, whether it applies to PPP in urban development projects. The first step is to engage in the confrontation. In the present study, confronting is interpreted as a form of mirroring. In order to avoid losing one's grip on assumptions, it is important to gauge one's own personal ideas against the perceptions of the other (cf. Vermaak, 2009, p. 221). This means allowing a connection between differences in perception, as a result of which it becomes clear that at least one party is experiencing a problem and what these differences in perception actually are.

2.2.1.3. Exploring. Here, exploring is interpreted as a way of jointly creating windows, based on new models or frames, from which reality can be viewed and given meaning (cf. Vermaak, 2009, p. 221). These new windows reframe because they replace the old ones. They enable us to see things in a different light, to weigh up the possibilities and eventually to achieve the best possible solution.

This is backed up in the process management and conflict literature as follows. Exploring possibilities for linking problems and solutions based on the various views is a central element of the formation of a 'new agenda' for impasses, which can be described as a dialogue of the deaf. The new agenda reframes the issue by basing the debate on new concepts (Van Eeten, 1999, p. 34). Moreover, looking for win-win solutions can considerably reduce the probability of future conflicts, or a repetition of conflicts (De Dreu et al., 2006, p. 927). Exploring possibilities for mutual solutions appeared, therefore, to be a potentially effective intervention that should be investigated to establish whether it is effective in the context of a PPP in urban development.

In addition to conflict interventions, four conflict context factors that reduce or even counteract conflict escalation have been distinguished (cf. De Dreu, 2005, p. 60; Giebels and Euwema, 2006, p. 150). Escalation is restricted in the event of a power balance; if accountability has to be given with regard to the conflict process; if 
there is a cooperative climate; and if there is low time pressure (De Dreu, 2005, p. 62). Let us examine these factors in the context of PPP projects.

\subsubsection{Conflict context factors}

2.2.2.1. Power balance. In the case of PPP projects in urban development, there is a power balance in the sense that, although there may be power differences, these are rarely so substantial that the strongest party can impose its will on the other party (Teisman, 2004, p. 421). Consequently, there does not appear to be a structural imbalance of power which, by definition, creates unequal conditions for the negotiation and escalation process. Some jostling for power and position is probably going on within those processes.

2.2.2.2. Accountability for process. Given the focus on negotiations between the local authority and project developers, this study assumes that public and private parties have to give an account to their backers with regard not only to achieved outcomes but also to the way these outcomes were achieved.

2.2.2.3. Climate of collaboration. Here, this factor is defined on a dimension between competitive and cooperative. A cooperative climate is a situation in which people believe that their goals are positively connected, with 'positively' meaning that the other party also wants to achieve those goals, enabling both parties to be successful (Tjosvold, 1998, p. 288). A competitive climate is a situation in which people believe that their goals are negatively connected; in other words, if one party achieves its goals, it is less probable that the other party will achieve its goals (Tjosvold, 1998, p. 289). The climate of collaboration is perhaps the most important factor for conflict prevention (De Dreu, 2005, p. 61). We assume that in the context of PPP in urban development projects, the climate of collaboration differs per project and may even differ from time to time within one and the same project.

2.2.2.4. Time. One of the characteristics of a PPP in the context of urban development is the long duration of projects. It was therefore assumed that the influence of the time factor is limited.

In short, in the context of a PPP in urban development projects, the factors of power balance, accountability for process, and time are 'standard' contributors to preventing escalation, with the climate of collaboration being the only one that can still vary. We therefore assert that a dysfunctional conflict can be prevented by creating a cooperative climate.

\subsection{Research questions}

Given the lack in the literature of interventions that, at an operational level, are suitable for the negotiating table and are also applicable to PPPs in urban development projects, a perspective for action was developed that contains the following interventions that are both likely to succeed and require research.

- Conflict interventions:

- Confronting differences in the perception of economic feasibility,

- Identifying assumptions that underlie these differences and

- Exploring these differences as possibilities for mutual solutions.

- Conflict context factor:

- Cooperative climate.

In light of the main research question (i.e. which interventions at an operational level can prevent dysfunctional conflicts in the practice of PPP in urban development projects?), the following two sub-questions were formulated:

- Which interventions contribute in the practice of PPP in urban development projects to preventing dysfunctional conflicts?

- Are the interventions that confront, identify and explore (CIE) differences in the perception of economic feasibility part of these interventions in a cooperative climate?

\section{Multi-case study}

\subsection{Methodology}

To address the research questions, a multi-case study was conducted. Based on the criterion of having considerable experience in a senior management position in a PPP in urban development, 20 experts were selected and asked about any cases that they knew about involving a PPP, a conflict about economic feasibility and a 'near-miss' dysfunctional conflict (i.e. a conflict that, although clearly escalated, did not become a dysfunctional conflict). Next, two key individuals involved in each case were asked whether they also believed that the case in question met the above three criteria. They were then asked whether they would be prepared to participate in the study - subject, of course, to confidentiality.

Questioning the 20 experts led to the identification of 12 case studies. These experts referred us to other experts 
with similar experience, but this did not lead to additional case studies. Two case studies were rejected following an initial interview because closer investigation revealed that they did not appear to meet the required profile of a PPP in urban development wherein a nearmiss dysfunctional conflict about economic feasibility occurred. Ten case studies remained.

A total of 21 interviews (three interviews in the first case and two in each of the other nine cases) were conducted; each lasted approximately 90 minutes. By putting the same question to at least two parties involved in the case, an attempt was made to ascertain the factuality of the project, at least as perceived by the participants. Secondary data such as brochures and newsletters were collected as background information. In the case of conflicting data, the data were rejected.

Because of the mix of an open and focussed character of the twofold research question, it seemed appropriate to adapt a strategy of a semi-structured study combining open and closed questions. The questionnaire was divided into three sections:

- The first section was intended to determine whether the case was suitable on the basis of control questions about the project, the PPP and the conflict.

- The second section was kept as open as possible with a broad orientation in order to gain as complete a picture as possible of what was done in practice (i.e. to address the first research question). Interview questions addressed issues relating to conflict, interventions and working climate, as well as economic feasibility and social relations.

- The third section went into more detail. It consisted of closed questions that addressed the second sub-question, namely whether the confrontation, identification and exploration of differences in perception about economic feasibility formed part of the intervention process in practice.

\subsection{Results}

\subsubsection{Single-case analysis}

First, all the cases were analysed in a single-case analysis. All 10 cases were analysed (cf. Lousberg, 2012). However, due to the limited space available for this article, we present the single-case analysis of only one case (case no. 5) in order to illustrate how the analysis was performed. The answers to the first section of the questionnaire for case no. 5 are:

- Project and PPP. The case involved an urban development project close to a large city. A temporary consortium was established in the form of a BV/CV (private limited company/limited partnership) construction in which four developers held a $49 \%$ share as the BV and the local council and a bank (until a few years ago) held $49 \%$ and $2 \%$ shares, respectively, as the $\mathrm{CV}$. As a result of the nationwide redrawing of municipal boundaries in the early 2000s, the district in question transformed from being a relatively small local authority into one of the largest local authorities within the Randstad conurbation. The project involved thousands of homes and tens of thousands of square metres of office space.

- Conflict - Essence and Escalation. The public body stated the following about how the conflict threatened to escalate: 'Things had become rather fraught, especially on the public side ... Tension was mounting quite high within the local council because of an insolvent estate, or so it was seen. At a certain point, money needed to be put into land development and the question arose as to whether this was a loan, whether it would be repaid and whether we would get relief on this loan. Things began to get very strained...' The public body stated the essence of the conflict to be ' ... that no contractual agreements had been made for times of economic downturn'. The developer stated that, 'Things threatened to escalate due to financial discontinuity. The coffers were empty as a result of the economic crisis' and '.. the essence of the conflict was that the private-sector organisations had negotiated too successfully at the outset. A huge imbalance arises if one party is able to negotiate a position for itself in which it has all the rights, full control and no obligations. After all, it was a small local council that had to contract out a huge project and didn't have the administrative resources to draft adequate contracts.'

The answers for all the cases are summarised in Table 1 .

Table 1 shows the investment volume in millions of euros, how the partners in the PPP were dependent on each other, what the conflict was about and the essence of the conflict. The last two characteristics turned out to be dependent on the perception of the interviewee.

Interventions were found by analysing the answers to the second section of the questionnaire. The answers were transcribed. Because of the two sub-questions (i.e. which interventions contribute in practice to preventing dysfunctional conflicts, and does this include CIE?), the transcriptions were analysed only to identify, and not relate, these interventions. For that, we applied the first step of open coding (Strauss and Corbin, 1998, p. 106) with the use of Atlas $\mathrm{Ti}$, by marking relevant passages, summarising them and assigning them an intervention name. Table 2 shows an example of case no. 5 . 
Table 1. Answers to the first section of the questionnaire.

\begin{tabular}{|c|c|c|c|c|c|}
\hline Case no. & Investment in $€$ millions & PPP dependency & Interviewee & Conflict about & Essence of the conflict \\
\hline \multirow[t]{3}{*}{1} & 50 & Residual land value & C & Land price & Cooperation code \\
\hline & & & D & Profit-sharing arrangement & Wall of incomprehension \\
\hline & & & G & Transparency of figures & Distrust \\
\hline \multirow[t]{2}{*}{2} & 150 & Residual land value & C & Minimum amount & Councillor's viewpoint \\
\hline & & & $\mathrm{D}$ & Behaviour of other party & Acceptance level reached \\
\hline \multirow[t]{2}{*}{3} & 200 & Residual land value & $\mathrm{C}$ & Estimate of profit and costs & Prejudice of the other party \\
\hline & & & D & Land price calculation & Lack of knowledge of the other party \\
\hline \multirow[t]{2}{*}{4} & 100 & Spread of risks $50-50 \%$ & C & Other party's goals & Insufficient financial cover \\
\hline & & & D & No guarantees from other party & Intransigence of other party \\
\hline \multirow[t]{2}{*}{5} & 600 & Spread of risks $50-50 \%$ & $\mathrm{C}$ & Lack of funds & Faulty contract \\
\hline & & & $\mathrm{D}$ & Financial discontinuity & Imbalance of power \\
\hline \multirow[t]{2}{*}{6} & 300 & Residual land value & C & Financial deficit & Increase in return \\
\hline & & & D & Revenue from homes & Different interpretations of offer \\
\hline \multirow[t]{2}{*}{7} & 850 & Spread of risks $50-50 \%$ & C & Compensation for loss or damage & Compensation scheme \\
\hline & & & $\mathrm{D}$ & Extra costs & Wrongly granted permit \\
\hline \multirow[t]{2}{*}{8} & 250 & Quality/Land value ratio & C & Developer's quality plan & Public reference images \\
\hline & & & D & Link between town and shopping centre & Control \\
\hline \multirow[t]{2}{*}{9} & * & Spread of risks $50-50 \%$ & C & Financial feasibility & Profit of private parties \\
\hline & & & D & Urban plan & Distribution of profit and costs \\
\hline \multirow[t]{2}{*}{10} & 185 & Profit-sharing & $\mathrm{C}$ & Changes to the plan & Developer too small \\
\hline & & & $\mathrm{D}$ & Changes to the plan & 'Simply money' \\
\hline
\end{tabular}

Note: C: city council representative; G: governmental representative; D: developer; *: unknown.

\subsubsection{Cross-case analysis}

When all the interventions from the 10 cases were compared (while applying the second step of open coding, Strauss and Corbin, 1998, p. 114), it became clear that, due to their similarity, many of the interventions could be placed in the same category. For example, 'Placing risk with the private-sector organisations' could be grouped together with the intervention taken from another case referred to as 'Converting revenue-dependent investment into guaranteed investment' in the 'Risk response' category. Similarly 'Working together', 'Drafting a plan together', 'Sharing the problem' and 'Creating/posing and solving a problem together' could all be grouped under 'Working together'. Apart from the interventions categorised under CIE, a total of 28 interventions were found, which were then reduced to 19 interventions (see Table 3).

The interventions identified in the transcripts were combined with the participants' answers to the third section of the questionnaire on the qualification of the climate of collaboration (see Table 3). A criterion was established that both the case's respondents had to agree about the nature of the climate of collaboration to determine whether it was cooperative or competitive. The climate in two cases was classified as competitive, in six cases as cooperative, and two cases as neutral or

Table 2. Example of the analysis of the transcriptions of the answers to the second section of the questionnaire for case no. 5 .

3. What action was taken during the conflict to ensure that the end result was achieved? .

C At a certain point, the commissioners, i.e. those at the level of top civil servant and supervisory board member, in effect addressed the following question during several informal sessions, 'Hey guys, how should the council deal with this far from favourable situation?' ... empty coffers, negative ground development, major strains due to amenities, more money, no facilities, more money. Then you get a millionaire's row on your doorstep ... money has to be poured into a bottomless pit - money that you may never get back - and you've got no amenities either. That's not something that can be easily explained as a council. So, we shared these issues with the parties involved and they understood the situation ... The first thing we did was to buy out the bank to gain a greater balance of control. We came up with a package of measures so that both the council and the private-sector organisations had a solid story ... The council borrowed the money, the bank was bought out and the private-sector organisations in effect gave a purchase guarantee without any presales and without any quota system instead a fixed price per square metre

D The bank was the only party that wanted to maximise the consortium's profitability; all other parties opposed it. This caused a great deal of tension. Moreover, there was a claim on what was termed reasonable return on equity capital due to their perspective that the consortium was purely an economic activity. This claim involved making policy decisions and acting in accordance with a desired return on equity capital. This paralysed both the public and the private parties in their attempts to take joint action. This is why we eliminated this particular party from the equation when renegotiating the contract's terms \& conditions and public and private obligations
Summarised and interpreted on interventions

\section{Personal contact \\ Sharing the problem \\ Removing \\ Placing risk with the private-sector \\ organisations}

Eliminating the one party that was acting purely in its own interests. 
Table 3. Overview of interventions found in the answers to the second section of the questionnaire and categorised.

\begin{tabular}{|c|c|c|}
\hline Intervention & Category & $\begin{array}{l}\text { Climate of } \\
\text { collaboration }\end{array}$ \\
\hline $\begin{array}{l}\text { Converting revenue-dependent to guaranteed investment, placing risk with private-sector organisation, } \\
\text { taking on other party's risk, transferring and spreading risk }\end{array}$ & Risk response & Cooperative climate \\
\hline Converting to alternative usage, maintaining no. of homes, increasing turnover and urban densification & Plan amendment & \\
\hline $\begin{array}{l}\text { Focus on quality and cash flow rate, focus on time-dependent revenues, costs and obligations, optimising } \\
\text { revenues, adjusting cash flow }\end{array}$ & $\begin{array}{l}\text { Focus on revenues and } \\
\text { cash flow }\end{array}$ & \\
\hline Best alternative without agreement ${ }^{\mathrm{a}}$ (BAWA) & $\begin{array}{l}\text { Focus on revenues and } \\
\text { cash flow }\end{array}$ & \\
\hline Provide alternatives & $\begin{array}{l}\text { Focus on revenues and } \\
\text { cash flow }\end{array}$ & \\
\hline Cost reallocation & $\begin{array}{l}\text { Focus on revenues and } \\
\text { cash flow }\end{array}$ & \\
\hline Personal contact, preliminary discussion & Personal discussion & \\
\hline $\begin{array}{l}\text { Working together, drafting a plan together, sharing the problem, creating/posing and solving a problem } \\
\text { together }\end{array}$ & Working together & \\
\hline Sell plan to third party & Removing & \\
\hline Threatening & Removing & \\
\hline Senior management intervention & Removing & \\
\hline Submission & Removing & \\
\hline Time-out & Removing & \\
\hline Third-party mediation & Removing & \\
\hline Larger mandate & Removing & \\
\hline Set up a briefing, problem setting & Confrontation & \\
\hline Putting assumptions forward for discussion, looking for where exactly the problem is & Identification & \\
\hline $\begin{array}{l}\text { Examining backgrounds, looking for the solution, thinking together about requirements and wishes, starting } \\
\text { exploration }\end{array}$ & Exploration & \\
\hline Putting it on the negotiation table & Confrontation & Competitive climate \\
\hline Replacing people & Removing & \\
\hline Personal discussion & Removing & \\
\hline Threatening & Removing & \\
\hline Submission & Removing & \\
\hline Senior management intervention & Removing & \\
\hline
\end{tabular}

${ }^{\mathrm{a}}$ Fisher et al. (2004).

undefined. At least two or three cases are required per group/subgroup in order to be able to compare the groups/subgroups of cases (Yin, 2003, p. 47).

In addition to this, the answers to the third section of the questionnaire relating to the interventions confronting, identifying and exploring differences in perceptions of economic feasibility were analysed and connected with the climate of collaboration at the time of conflict as indicated by the participants.

It transpires that in all cases, confronting views related to feasibility took place during the conflict. In addition, nearly all cases involved assumptions related to feasibility and the different ways in which this was perceived. The answers also show that confronting views on economic feasibility is related not so much to confronting facts, but to confronting underlying assumptions about the expected costs and/or risks, assumptions that are dependent on the perception of the participant in the conflict. It also appears that those assumptions or backgrounds to the differences in perception are identified only in the case of conflicts in a cooperative climate. In a competitive climate, the focus is still on assumptions and differences in perception, but these are not specifically identified. The various possibilities open to the parties are again explored only in a cooperative climate.
As indicated by the analysis of the answers to the second section of the questionnaire (see Table 3), the analysis of the answers to the third section of the questionnaire therefore shows that all the cases with a cooperative climate involved the confronting, identifying and exploring of differences in perception of economic feasibility, but that the cases with a competitive climate only involved confronting.

Finally, all interventions were assessed to see whether they could be categorised under economic feasibility or social relationship.

Summarising, the analysis of the answers to the second and third sections of the questionnaire identified interventions that contribute to the prevention of dysfunctional conflicts (see Figure 1).

\section{Discussion}

\subsection{Cooperative climate versus competitive climate}

It is perhaps surprising to find an intervention such as 'threatening' or even 'removing' as one of the interventions in the social relations section of the cooperative climate. However, Figure 1 shows all the interventions that are classified as contributing to the prevention of 


\begin{tabular}{|c|c|c|}
\hline & Risk response, Plan amendment, Focus on revenues and cash flow, Best \\
alternative without agreement, & Provide alternatives, Cost reallocation
\end{tabular}

Figure 1. Interventions - consolidated. *Fisher et al. (2004: 123).

dysfunctional conflicts, including the aforementioned and a competitive climate. That is remarkable, because although it is contra-intuitive, it makes sense from a practical point of view. As we have noticed in this practice, even in a climate that is retrospectively classified as cooperative, there will have been moments of threatening behaviour or worse. And even though a climate has been classified as competitive, it appears to be possible to prevent the conflict from becoming dysfunctional. It is also interesting to see how the interventions found in a cooperative climate are much richer than they are in a competitive climate.

According to Tjosvold (1998), the outcome in a cooperative climate is characterised by high-quality decisions in contrast to low-quality decisions in a competitive climate. This appears to correspond to the finding that a whole host of interventions can be found in a cooperative climate, whereas this is much less the case in a competitive climate. It seems to be mainly determined by whether the participants believe that their goals are positively related (Tjosvold, 1998, p. 291). However, because in the current study the existence or absence of a shared goal was not investigated, confirming that this finding could be the subject of further research.

In addition, whereas in a cooperative climate the interaction is characterised by constructive controversy and mutual exchange, the interaction in a competitive climate of collaboration is characterised by discussion avoidance, a closed attitude and an attempt to coerce (Tjosvold, 1998, p. 291). This contradicts our findings, namely that coercion takes place in both climates. Practice appears to be more messy than Tjosvold's results suggest. We believe that in this practice, negotiations can be characterised as an alternation between a distributive strategy and an integrative strategy (Saner, 2005, p. 130) within a dominant cooperative or a dominant competitive climate. But this has to be investigated further.

\subsection{Economic feasibility and social relationship}

The analysis confirms that all interventions can be classified within the distinction between economic and social perspective that is at the basis of the theoretical framework of this research. The distinction corresponds to research on large-scale engineering projects in recent years. In 2012, Hoezen et al. distinguished between formal and informal contracting processes. Dewulf and Kadefors (2012) state: 'There are two dimensions of any exchange relationship: the formal contract and the actual interaction that takes place.' Also in 2012 Henisz et al. contrasted economic and legal perspectives with sociological and psychological perspectives in their article 'Towards a unified theory of project governance.' In 2014, Walker and Lloyd-Walker distinguished a relational approach contrary to the traditional substantial approach in the managing of alliance projects. Finally, in 2015 Bygballe et al. added that Dewulf and Kadefors had shown in 2012 that the formal contract and the informal relationship interact. The distinction in the current study between economic feasibility and social relationship seems to correspond with that.

These authors seem to suggest that while communicating at a formal/economic/legal/feasibility level, communication also takes place at an informal/sociological/ psychological/relational level (cf. Schulz von Thun, 2003, pp. 15-17) and that these two levels interact. Here, this is interpreted as: while working on the business contract, a social contract (e.g. Anvuur and Kumaraswamy, 2007) is formed. It would be fascinating to follow this line of thought and try to find more empirical confirmation of it. Future research could investigate, 
for example, what the relationship is between interventions concerning economic feasibility and those concerning social relationship, and how the latter helps the former and how they influence each other.

\section{Conclusion}

The key research question of this study was: Which interventions at an operational level can prevent dysfunctional conflicts in the practice of PPP in urban development projects?

On the basis of a literature study, this question was divided into two sub-questions:

- Which interventions contribute in practice of PPP in urban development projects to preventing dysfunctional conflicts?

- Are the interventions that CIE differences in the perception of economic feasibility part of these interventions in a cooperative climate?

Including CIE, a total of 31 interventions were identified and then reduced to 19 interventions (see Figure 1). This answers the first of the sub-questions. Because the CIE interventions are included in these identified interventions, the second sub-question can be answered in the affirmative. All identified interventions contribute to preventing dysfunctional conflicts, from which those that occur only in a cooperative climate, including CIE, contribute to the realisation of a more cooperative climate of collaboration. With that, the key research question is answered.

All identified interventions address aspects of economic feasibility and social relationship in both a cooperative and a competitive climate. We conclude that dysfunctional conflicts can be prevented by managing economic feasibility and social relationships.

\section{Contribution, limitations and generalisation}

This study contributes to the field of the management of large PPP engineering projects by bridging the gap in the literature on interventions that prevent dysfunctional conflicts that, at an operational level, are suitable for the negotiating table' and are applicable to PPPs in urban development projects. Although the study was limited to Dutch PPPs in urban development projects that satisfy the three criteria of a shared investment risk, a non-hierarchical relationship between parties and the phase prior to signing a realisation contract, the results of this study also apply to other PPP projects under certain conditions.
Concerning the 'suitability for the negotiation table', we want to extend the study. Because the research was a retrospective investigation, respondents reflected only on what had been done at this table, not on what had actually been said. It would be very interesting to investigate (e.g. by observation) what is said during such negotiations, and we feel that this should be the very next step in continuing the current research.

Concerning the applicability to PPPs in urban development projects in general, the study was limited to PPPs in urban development projects in the Netherlands and, as mentioned in the introduction, the situation in other countries can differ fundamentally regarding, for example, shared risk. If a partnership does not satisfy one or more of the three criteria mentioned above, it is less likely that the study's results can be applied.

The study's results can partly be generalised to PPPs not set up for urban development projects: social relationship-related interventions are not specific to urban development projects, but the interventions taken in respect of economic feasibility as identified in practice are highly specific to urban development projects. Moreover, if the interventions taken in respect of economic feasibility are interpreted in more general terms of feasibility like political or environmental feasibility - as long as it is crucial for the survival of the public-private partnership - we believe it is likely that the results of this study will apply to other PPPs.

\section{Disclosure statement}

No potential conflict of interest was reported by the authors.

\section{References}

Anvuur, A. and Kumaraswamy, M. (2007) 'Conceptual model of partnering and alliancing.' Journal of Construction Engineering and Management, 133(3), 225-234.

Brady, T. and Davies, A. (2014) Managing structural and dynamic complexity: a tale of two projects. Project Management Journal, 45(4), 21-38.

Bult-Spiering, M. (2003) Publiek Private Samenwerking. De Interactie Centraal, University of Twente, Enschede.

Bult-Spiering, M. and Dewulf, G. (2008) Strategic Issues in Public Private Partnerships. An International Perspective, Blackwell Publishing, Oxford.

Bygballe, L.E., Dewulf, G. and Levitt, R.E. (2015) The interplay between formal and informal contracting in integrated project delivery. The Engineering Project Organization Journal, 5(1), 22-35.

De Bruijn, H. and Leijten, M. (2005) Publiekprivate samenwerking bij infrastructuurprojecten, in Dutch Lower House session [Tweede Kamer, vergaderjaar] 2004-2005, 29,283 , nr. 10. 
De Caluwé, L. and Vermaak H. (2006) Leren Veranderen. Een handboek voor de veranderkundige, Kluwer, Deventer.

De Dreu, C. (2005) Bang Voor Conflict? De Psychologie van Conflicten in Organisaties, Koninklijke Van Gorcum, Assen.

De Dreu, C.K., Beersma, B., Euwema, M.C. and Stroebe, K. (2006) Motivated information processing, strategic choice, and the quality of negotiated agreement. Journal of Personality and Psychology, 90(6), 927-943.

De Leeuw, A. (2002) Bedrijfskundig Management - Primair Proces, Strategie en Organisatie, Koninklijke Van Gorcum, Assen.

De Moor, W. (1991) Stress en Conflictmanagement, een constructivistische benadering, Bohn Stafleu van Loghum, Houten.

Dewulf, G. and Kadefors, A. (2012) Collaboration in public construction-contractual incentives, partnering schemes and trust. Engineering Project Organization Journal, 2, 240-50.

Duke, R. and Geurts, J. (2004) Policy Games for Strategic Management - Pathways into the Unknown, Dutch University Press, Amsterdam.

Enterprise Risk Services (2009), Benchmark PPS in Vlaanderen, Wat Kunnen we Leren uit het Buitenland?, Kenniscentrum van Publiek Private Samenwerking van de Vlaamsche Overheid, Brussels.

Evers, F. and Susskind, L. (2009) Het kan wel! Bestuurlijk Onderhandelen Voor een Duurzaam Resultaat, Uitgeverij MGMC, Haarlem.

Fisher, R., Ury, W. and Patton, B. (2004) Excellent Onderhandelen, Business Contact, Amsterdam.

Giebels, E. and Euwema, M. (2006) Conflictmanagement; Analyse, Diagnostiek Eninterventie, Wolters Noordhoff, Groningen/Houten.

Henisz, W.J., Levitt, R.E. and Scott, W.R. (2012) Toward a unified theory of project governance: economic, sociological and psychological supports for relational contracting. The Engineering Project Organization Journal, 2(March-June), 37-55

Hoezen, M., Voordijk, H. and Dewulf, G. (2012) Formal and informal contracting processes in the competitive dialogue procedure: a multiple-case study. Engineering Project Organization Journal, 2, 145-58.

Jehn, K. (1997) Affective and cognitive conflict in work groups: Increasing performance through value-based intragroup conflict, in De Dreu, C.K.W. and Van de Vliert, E. (eds.) Using Conflict in Organizations, Sage, London, pp. 87-100.

Kouwenhoven, V. (1991) Publiek Private Samenwerking. Van Mode Naar Model, Eburon, Delft.

Lousberg, L. (2012) Sturen op Haalbaarheid en Relatie, Delft University of Technology, Delft.

Mahalingam, A., and Delhi, V.S.K. (2012) A contested organizational field perspective of the diffusion of public-private partnership regimes: evidence from India. Engineering Project Organization Journal, 2, 171-86.

Matos Castaño, J, Hartmann, T., Dewulf, G.P.M.R. and Van Huffelen-de Kort, I.A.T. (2015) 'What is going on and what should we do?' Divergent frames in multifunctional projects. The Engineering Project Organization Journal, 5 (1), 36-48

Pinto, D. (2004) Interculturele Communicatie, Conflicten en Management, Bohn Stafleu Van Loghum, Houten.

Saner, R. (2005) The Expert Negotiator, Martinus Nijhoff, Leiden/Boston.

Schruijer, S. and Vansina L. (2007) Samenwerkingsrelaties over de organisatiegrenzen, Theorie en Praktijk. Management en Organisatie, 61(3/4), 203-218.

Schulz von Thun, F. (2003) Hoe Bedoelt U?, WoltersNoordhoff bv, Groningen/Houten.

Smulders, F. (2006) Get Synchronized. Building the Gap Between Design \& Volume Production, Delft University of Technology, Delft.

Strauss, A. and Corbin, J. (1998), Basics of Qualitative Research: Techniques and Procedures for Developing Grounded Theory, London, Sage.

Teisman, G. (2004) Ruimtelijke ontwikkeling vereist procesmanagement, in De Bruijn, H., Teisman, G.R., Edelenbos, J. and Veeneman, W. (ed.) Meervoudig Ruimtegebruik en het Management van Meerstemmige Processen, Lemma, Utrecht.

Thomas, K. and Kilmann, R. (1974) Thomas-Kilmann Conflict MODE Instrument, XICOM Tuxedo, New York.

Tjosvold, D. (1998) Cooperative and competitive goal approach to conflict: accomplishments and challenges. Applied Psychology: An International Review, 47(3), 285-313.

Van der Meij, J., ter Beek, H., Postema, A. and Van der Putten, M. (2000) Inventarisatie Faal-en Succesfactoren van Lokale PPS Projects, Kenniscentrum PPS, The Hague.

Van Dongen, H.J., de Laat, W.A.M. and Mass, A.J.J.A. (1996) Een Kwestie van Verschil, Conflicthantering en Onderhandeling in een Configuratieve Integratietheorie, Eburon, Delft.

Van Eeten, M. (1999) Dialogues of the Deaf: Defining New Agendas for Environmental Deadlocks, Delft, dissertation Delft University of Technology.

Vermaak, H. (2009) Plezier Beleven aan Taaie Vraagstukken. Werkingsmechanismen van vernieuwing en weerbarstigheid, Kluwer, Deventer.

Vollmer, A. and Seyr, S. (2013) Constructive controversy research in the business organizational context - a literature review. International Journal of Conflict Management, 24 (4), 399-420.

Walker, H.T. and Lloyd-Walker, B.M. (2014) The ambience of a project alliance in Australia. The Engineering Project Organization Journal, 4(1), 2-16.

Weening, H. (2006) Smart Cities: Omgaan met Onzekerheid, Delft University of Technology, Delft.

Weick, K. (1995) Sensemaking in Organizations, Sage, London.

Yin, R. (2003) Case Study Research, Design and Methods, Sage, London. 